\title{
Acceleration and Deceleration in the Internationalization Process of the Firm
}

\author{
Martin Johanson $^{1,2} \cdot$ Igor Kalinic $^{3}$
}

Received: 31 October 2013/Revised: 27 August 2015/Accepted: 29 December 2015/

Published online: 29 September 2016

(C) The Author(s) 2016. This article is published with open access at Springerlink.com

\begin{abstract}
By adopting a processual and dynamic view on internationalization, we develop the concepts of acceleration and deceleration, providing analytical tools to enhance our understanding of the non-linearity and multidimensionality of internationalization. We argue that acceleration and deceleration are embedded in the internationalization process and are a consequence of the firm's capability to absorb and integrate acquired knowledge, and to find and exploit opportunities. In addition, we advance the idea that changes in speed are further influenced by how the firm integrates and coordinates the resources it has deployed within and across various internationalization dimensions. Thus, it emerges that the overall evolution of commitment to internationalization is more complex than received theories tend to present; therefore, empirical studies should aim to include a wide set of international activities and processes embedded in time.
\end{abstract}

Keywords Internationalization $\cdot$ Speed $\cdot$ Acceleration $\cdot$ Deceleration $\cdot$ International commitment $\cdot$ Time $\cdot$ Process

\section{Introduction}

Speed has, over the last decade, gained a central position in research into firm internationalization (Jiang et al. 2014; Vermeulen and Barkema 2002; Casillas and Acedo 2013; Casillas and Moreno-Menéndez 2013; Acedo and Jones 2007; McDougall et al. 2003), as it is often claimed that international expansion takes

\section{Martin Johanson}

martin.johanson@miun.se

1 Department of Business, Economics and Law, Mid Sweden University, Sundsvall, Sweden

2 Department of Business Studies, Uppsala University, Uppsala, Sweden

3 Leeds University Business School, University of Leeds, Leeds, UK 
place at a higher speed than received theory predicts (Kalinic and Forza 2012). In this literature, speed of internationalization is seen as the relationship between international commitment and time (Chetty et al. 2014; Vermeulen and Barkema 2002). However, we argue that the dominant approach to studying speed is limited by its inattention to process. We provide a more dynamic perspective, moving beyond speed to consider change in speed, and from a single process to multiple interrelated processes. We argue that this shift from a static to a dynamic explanation provides new theoretical insights into the nature of internationalization processes.

In proposing a more dynamic understanding of speed, we address two gaps in current theories on firm internationalization, both of which are especially applicable to the study of born globals. The first gap is mainly conceptual: the most popular concepts - such as speed, pace, and rapidity-are assumed to be constant throughout the process (Acedo and Jones 2007; Coeurderoy and Murray 2008). This is despite the fact that there are qualitative case studies (e.g., Bell et al. 2003; Kalinic et al. 2014) reporting that the internationalization process is usually not incremental, linear, and gradual. Rather, it can be described as leapfrogging, consisting of both small and big steps (Hedlund and Kverneland 1985). The second gap is to be found in the literature on speed of internationalization and concerns the over-simplification of the process; that is, most studies consider the speed of one type of international commitment only (e.g., Khavul et al. 2010; Ramos et al. 2011). This overlooks the diverse activities of internationalizing firms, which can be engaged not just in international sales, but also importing and different forms of investment. As a result of these limitations of the existing literature, the view of internationalization that predominates is of a single, linear progression.

This study challenges that dominant view by theoretically accounting for changes in speed over time. We extend the scope of existing studies, beyond the limited time period and limited set of activities that are typically included, in order to develop a deeper and more relevant understanding of internationalization as a non-linear, multidimensional, and irregular process. First, in contrast to the majority of studies on speed (e.g., Khavul et al. 2010; Morgan-Thomas and Jones 2009; Musteen et al. 2010), we argue for a conceptualization that grasps the multidimensionality of internationalization (Casillas and Acedo 2013). The internationalization process is more complex than it would seem based on its treatment so far in the literature. Second, by developing the concepts of acceleration and deceleration, the study allows for a non-linear and irregular process characterized by changing speed, instead of the assumption of constant speed. Finally, we provide a theoretical explanation for patterns in the change of speed. We argue that acceleration and deceleration are consequences of the firm's capability to absorb and integrate the knowledge it acquires, and to find and exploit opportunities, but we also advance the idea that changes in speed are a result of how the firm integrates and coordinates the resources it has deployed within and across various internationalization dimensions. As the complexity of its operations increases, the need for coordination grows.

We develop our dynamic understanding of speed by anchoring the concepts we use in internationalization process theory (Johanson and Vahlne 1977). We distinguish process models from stage models (e.g., Bilkey and Tesar 1977; 
Cavusgil 1980). Both types of models recognize the importance of time, but the latter proposes that specific stages can be observed and that they follow a specific order. The stages are manifestations of the firm's international commitment during a specific period. Thus, they are linear models. The process models, on the other hand, focus on the dynamics of the process, and thereby make non-linearity of internationalization possible. They provide some explanation for why a firm increases or decreases its international commitment over time. Thereby, we recognize the dynamics and complexity of internationalization and we refer to the process as a course or pattern over time, whereby firms perform activities and invest resources in order to become international. The implications of this process perspective are that time is critical and that the dynamic driving internationalization is the interplay among activities performed, knowledge acquired, and commitment made in terms of resources invested in foreign markets over time.

As we need to define speed before we can discuss acceleration and deceleration, the next section provides definitions of speed by identifying its components: international commitment and time. The subsequent section outlines how internationalization involves changes in speed by means of two illustrative cases. ${ }^{1} \mathrm{We}$ then develop a theoretical explanation for changes in the speed of internationalization. Finally, we wrap up by suggesting promising research areas.

\section{Speed of Internationalization}

In physics, speed is defined as the distance traveled divided by the time taken to travel it, while acceleration or deceleration is the rate of change of speed. ${ }^{2}$ In an internationalization context, we apply these concepts in a metaphorical way. That is, we enrich our conceptualization of internationalization speed by drawing on the concept of physical speed. In this paper, we use the concept of acceleration of internationalization to signify the increase in the rate (i.e., speed) of international commitment. For example, acceleration of internationalization has occurred if the number of established entities abroad in the current year is higher than in the previous year. However, in making use of the concept of acceleration, it is important to note that we are not suggesting that acceleration of internationalization is identical to acceleration in physics; as we shall discuss, the differences between the social and physical worlds also need to be kept in mind.

Just as we are not using the concepts speed/acceleration as they are in physics, neither are we using "acceleration" in the same way as it has been popularized in the born global literature. "Accelerated internationalization" is a label often applied to distinguish born globals by underlining that they, unlike other firms, begin to internationalize soon after inception (e.g., Shrader et al. 2000). Acceleration in this sense simply refers to the greater speed of the first steps of internationalization

\footnotetext{
1 In this work, we do not use the empirical evidence as a basis for testing or building a theory. Instead, the examples are used to illustrate the key elements and relationships of our conceptual work (see Doz 2011). A description of how data were collected and used can be found in "Appendix".

2 To be exact, we should distinguish between average speed (as defined above) and instantaneous speed (which represents the speed in an instant). Nevertheless, this distinction is beyond the scope of this paper.
} 
compared to other firms following "traditional" internationalization patterns or compared to earlier generations of firms. Previous studies, especially in the born global literature (e.g., Oviatt and McDougall 2005; Shrader et al. 2000), do not describe change in speed, and acceleration is not studied as an explicit concept or applied to specific firms' internationalization, but if we are loyal to the original meaning of the word (as used in other disciplines), "acceleration" reflects change in speed.

Deceleration has, to our knowledge, never been studied as an explicit concept in the internationalization literature. Deceleration does not mean exit from a market; increasing internationalization can be characterized by high, but decelerating, speed. While acceleration is the rate at which internationalization speeds up, deceleration is the rate at which it slows down. Thus, if we analyze a specific firm's internationalization, we can identify phases in which the internationalization occurs at a high speed but, at the same time, decelerates.

In order to be able to study acceleration and deceleration, it is necessary to analyze variations in speed. In physics, determining speed involves calculating the physical distance covered by an object in a certain period of time (speed $=$ distance/time). Calculating the speed of internationalization therefore requires specifying how "distance" - that is, change in international commitment-is to be conceived and measured (the numerator), as well as the time unit to be used (the denominator). We will examine each of these issues in turn.

\subsection{International Commitment}

While in physics, physical distance is measured to determine speed, equivalent measures are not as straightforward when it comes to internationalization. In internationalization process theory (the Uppsala Model), international commitment is conceived as the extent to which resources are invested and activities performed in foreign markets (Pedersen and Petersen 1998; Johanson and Vahlne 1977). By investing resources and undertaking activities in foreign markets, a firm forgoes alternatives and becomes dependent on its international operations. The existing literature has concentrated on four different measures of international commitment: degree of dependence on export; degree of dependence on import; number of legal entities established in other markets; and number of foreign markets in which the firm is operating (Welch and Luostarinen 1988; Casillas and Acedo 2013). From a more dynamic perspective, these different commitment activities can be viewed as distinct but interrelated sequences. As our focus in this paper is on acceleration and deceleration, we are mainly interested in how these sequences evolve over time. By concentrating on these four commitment sequences, we are not suggesting that these are necessarily the only ones involved in developing the firm's international commitment; however, they are the ones that have received the most attention in the existing literature. In this section, we will discuss each in turn.

A firm's international commitment can be partly captured by its exporting activities. Thus, how much the firm is selling to foreign markets indicates its degree of dependence on international operations; its dependence is a consequence of how much of its total turnover results from sales in markets other than its domestic one 
(Barrett and Wilkinson 1986; Bilkey and Tesar 1977; Moon and Lee 1990). Export activities are commonly used to measure international commitment. The most established measurement of speed is the number of years from inception of the firm to the year when international sales begin (Hilmersson and Johanson 2015), and the share of international sales is commonly used in the definition of a born global (e.g., Chetty and Campbell-Hunt 2004; Knight and Cavusgil 1996; Servais et al. 2007a, b). However, besides Morgan-Thomas and Jones (2009), there are no studies on the sustainability of speed, measured as sales abroad following the year when the first sale occurs.

Importing has been recognized as an important internationalization dimension (Welch and Luostarinen 1993; Zhou et al. 2007). It captures the activities performed during the process of internationalization and it reflects the firm's dependence on an international environment, but the literature has so far not taken into account the speed of importing. Sourcing from other markets has become more crucial with the advent of global value chains and has increased the international integration of various functions in the firm, as, for instance, import and export are interrelated (Welch and Luostarinen 1993; Zhou et al. 2007). However, how import relates to export, number of foreign markets, and legal entities over time continues to be under-studied (for exceptions, see Karlsen et al. 2003; Servais et al. 2007a, b).

The number of legal entities established abroad reflects the extent to which the firm is organizationally integrated into foreign markets. The number of legal entities established abroad during a specific period of time has previously been used as a measure of speed (Jiang et al. 2014; Lin 2012; Musteen et al. 2010; Vermeulen and Barkema 2002; Wagner 2004). The Uppsala Model used the establishment of sales subsidiaries, and eventually production facilities, as evidence of increasing commitment to internationalization (Johanson and Wiedersheim-Paul 1975).

Finally, the number of foreign markets where the firm is operating (e.g., Weerawardena et al. 2007) needs to be integrated into the commitment concept. There is a vast amount of research on multinationality (see Contractor 2007; Li 2007), and in Oviatt and McDougall (2005) and Zhou (2007), the number of export markets is the manifestation of internationalization. Additional markets signify that the firm needs to integrate additional procedures for various situations, as markets tend to be different in terms of cultures and institutions; moreover, multiple markets signify that the firm is less dependent on a single market and, thus, the importance of international operations increases.

\subsection{Time}

Time is one of the main components of the definition of the internationalization process, which leads to three issues that have to be solved. The first is the question of which time unit should be used that best encompasses the process. In most studies the time unit applied is "years", reflecting the longer duration of most internationalization processes. An exception is a recent study on speed which uses "days" as the time unit (Casillas and Moreno-Menéndez 2013). The time unit used is closely related to the aspect of international commitment that is the focus of the study. On a micro level, much happens as the firm internationalizes, including communication 
with customers and authorities, making decisions on products and prices, etc. Time units other than "years" might be more appropriate when examining these microprocesses, whether they are episodes, events, or people's interactions and decisions. As this study aims to contribute to internationalization process theory and we see the process in a long-term perspective, we use "years" as the time unit.

The second issue relates to the start and end of the process studied. In the born global literature, internationalization and the development of the firm are viewed as an integrated process. The start of this process is almost always defined as the time of the firm's inception (Coeurderoy and Murray 2008; Khavul et al. 2010; Luo et al. 2005; Pla-Barber and Escribá-Esteve 2006; Zucchella et al. 2007), even though what happens before inception may be integral to the process (Hewerdine and Welch 2013). For example, managers bring their prior experience and networks to the firm, which influences internationalization (Coviello 2006). The process ends when internationalization begins (Chetty and Campbell-Hunt 2004; Knight and Cavusgil 1996; Madsen and Servais 1997). With respect to internationalization process theory, what happens after internationalization starts is not in focus (Johanson and Martin Martin 2015).

Internationalization process theory (e.g., Johanson and Vahlne 1977) analyzes the process as starting when the firm makes its first entry into a foreign market, but takes into consideration what happens after internationalization has begun. Although we recognize the importance of the entrepreneurs' background and the firm's pre-inception history, we take as our starting point the inception of the firm, but we do not stop when the first foreign markets are entered, nor shortly afterwards. In order to capture further aspects of the acceleration of internationalization, we need a process view that continues long after the first foreign market entry. In this, as in other respects, in this study we are closer to internationalization process theory than to the born global approach.

A third issue is the identification of the periods that we compare, characterized by different speeds and/or accelerations. In other words, if we say that in the first period internationalization was slower than in the second period, then it is necessary to identify the milestones delimiting those periods. One possibility consists of arbitrarily predetermining the duration of the periods; for example, the first 3 years of the internationalization, the second 3 years, etc. A second possibility consists of letting the milestones emerge from the analysis itself, with regard to the context under study. In this paper, we pursue the second approach. We suggest identifying the milestone events when change in speed occurs, following the critical incident technique. The critical incident technique is a set of procedures used to collect direct observations of activities that represent key turning points. It is particularly useful in analyzing processes influenced by human behavior (Butterfield et al. 2005; Flanagan 1954), such as the internationalization process of a firm. However, choosing the milestones is not always easy and it is conditioned by the subjectivities of both the research participant and the researcher. Thus, for example, the initial period could be longer or shorter (depending on when one identifies that the initial speed and/or acceleration have changed) and, therefore, the average speed and/or acceleration of that period could be different. It is important to note that the subjectivity is not about 
the speed itself, but about the periods that are (arbitrarily chosen) to be compared. We elaborate more on this point in the following section.

\section{Capturing Acceleration and Deceleration}

In the case of speed, one must identify two milestones in time and then estimate the international commitment at each of these milestones. For instance, we might find that Firm A had a speed of international commitment of three market entries per year during its first 10 years of existence, while Firm B had a speed of two market entries per year during its first 8 years. The start and end of this first period represent two milestones. If we add ten more years of existence for both firms, there are now three milestones. If we assume that Firm A during this second period enters five new markets, while Firm B enters 40 new markets, the process for both firms is characterized by a change of speed. Firm A's internationalization decelerates from three market entries per year to 0.5 entries per year, and Firm B's internationalization accelerates to four market entries per year. This continues for both firms so that at the end of the time period examined, the firms are operating in 35 and 56 markets respectively, but the process has undergone phases of acceleration and deceleration and there is no exit or de-internationalization. Therefore, in order to capture acceleration and/or deceleration, we must identify at least three points in time and, at each of these points, estimate the degree of international commitment. ${ }^{3}$ We can thereby specify the speed between the first two milestones and the speed between the second and the third milestones. By comparing these two periods, we are then able to specify changes in speed during the process.

In the example, the milestones and time periods were arbitrarily predetermined by the researcher. However, given the specificity of the social world, we suggest that in this case the identification of periods should be context-dependent as that would allow for a more complete understanding of the phenomenon under study. We argue that the milestones should be identified so that both changes in speed and constant speed occur. Consideration also needs to be given to whether longer or shorter periods are analyzed; a study which can include multiple time periods and temporal heterogeneity would, we argue, be advantageous. In addition, in the example with Firm A and Firm B, we referred only to one form of commitment, namely the number of markets entered, but other dimensions may have different speeds and patterns. Once changes in speed are included in the analysis, the internationalization process appears less linear and regular than if the speed of internationalization was averaged out, smoothing away changes of speed in this process.

We can illustrate this by presenting examples of two firms from Italy, to which we now turn. We decided to use two cases to be able to illustrate all the key elements and relationships of our conceptual work. The main criterion for selecting the two firms was that they had to have made the four types of commitment to

\footnotetext{
${ }^{3}$ We refer to average acceleration rather than to instantaneous acceleration (which represents the acceleration in an instant).
} 
several foreign markets. In order to capture the process, the cases span over 16 and 22 years respectively. The cases are similar in that both are from the manufacturing sector, although one operates mainly in B2B markets and is more technology driven while the other is a producer of consumer products and operates in a mature technology sector. We will return to the implications of this industry context when discussing future research and further conceptual development.

The first firm is called Yamatek; it has 75 employees and produces compressors. The firm was founded in 1992 (see Fig. 1). In the beginning, it focused on creating close relationships with major domestic customers. Its first contact with international markets was in 1995, when the firm began exporting to Germany and Finland. International expansion continued over the subsequent years and, in 1998, the firm was exporting to nine countries in Western Europe, but without making investments in legal entities abroad. Neither did it import from other countries. In 1998, the firm approached the Eastern European markets and, in the same year, it established its first legal entity abroad, a $50 \%$-owned joint venture in Romania, which was a trading firm. The venture did not have the desired success and, after few months, the firm ended the collaboration. Expansion outside European borders continued through a network of dealers into Australia, South Korea, and Venezuela and, 3 years later, the firm was exporting to 24 countries. In parallel, it also slowly began to source from abroad and, in $2001,5 \%$ of the total purchased volume was imported.

A new step in the internationalization process occurred in 2001, when Yamatek established a production unit in Bosnia while exploring market possibilities in the Balkans. In addition to running the subsidiary in Bosnia, internationalization continued: both the number of markets served and imports increased, at the same time as the firm continued to establish its own legal entities abroad. In 2006, Yamatek initiated a joint venture in Brazil and, in 2008, it established a similar firm in Poland.

Yamatek expanded internationally following multiple paths, with each path experiencing changes in speed over time. In Fig. 1, four periods are identified. Internationalization began with exports just 3 years after inception. In the second period, exports increased from 5 to $10 \%$ of the turnover, but after the sixth year international sales accelerated significantly. International sales continued to increase, but at a slower speed after the ninth year. Nine years after inception, the volume sourced abroad was only $5 \%$, but, following this, the growth accelerated slightly and, 16 years following the establishment of the firm, the volume purchased abroad had grown to comprise $20 \%$ of the total volume of purchased products. Just 6 years after inception, the firm established a $50 \%$-owned trading firm in Romania. However, the speed of establishment of legal entities abroad decelerated as the trading firm was closed; nonetheless, Yamatek did not withdraw completely as it maintained some sales. In 2001, internationalization accelerated once more, when the firm established a production subsidiary in Bosnia, and went on to establish approximately one legal entity every second year for the next 7 years. From the third year to the sixth year following inception, the growth in the number of foreign markets accelerated. After this, the speed increased even 


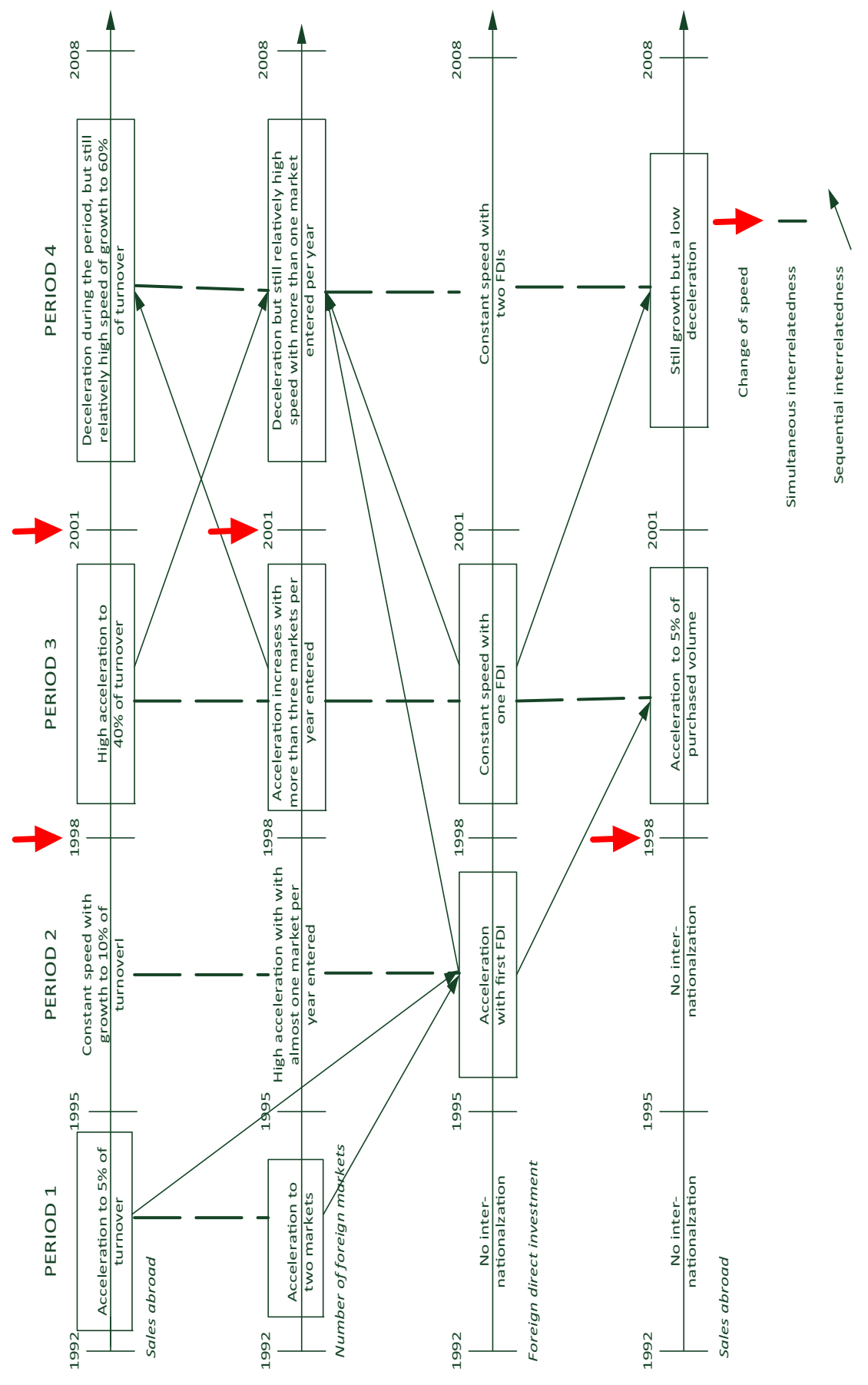

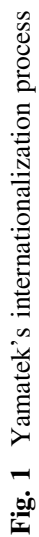


more and, after 9 years of existence, the firm was operating in 24 markets. Thereafter, growth decelerated, but continued.

In contrast to Yamatek, VestoBene is part of a more traditional, less technologydriven, sector. In addition, its internationalization process was pulled rather then pushed (at least in the beginning). In 1986, the founder, after having acquired some experience in the textile sector, established VestoBene to operate as a subcontractor for major Italian brands. Two years after inception, in 1988, the firm began to export, as foreign firms' agents found its products interesting (see Fig. 2). It was selling to German firms, and its exports that year amounted to $10 \%$ of total sales. Soon after, internationalization soared. In 1992, through the acquisition of a Nordic brand, international sales reached $50 \%$ of total sales, and the firm was active in 15 foreign markets. At this point, it was not yet importing. Internationalization continued over the next 4 years. Exports increased to $75 \%$ of total sales in 1996, and the firm acquired a German textile firm. The production and the machines were transferred to Italy, and the firm used the new branch for commercial and logistical purposes. It expanded its presence in Germany through its network of six retail stores. In the following years, it opened retail stores in Italy, Spain, France and the USA.

Some years later, the increased sales, together with the shortage of pricecompetitive subcontractors in Italy, forced the firm to search for subcontractors abroad. In 2002, it established a production-oriented subsidiary in Romania. Six months after the first contact in Romania, it had moved $40 \%$ of its entire production abroad and employed 70 people abroad. Immediately and simultaneously, it began cooperating with local subcontractors by creating a copy of the Italian production network. In the following years, thanks to its presence in the local market, the firm sourced final products from Romania in order to complete its collections. After some years of production in Romania, labor costs were rising and unemployment was falling. The firm decided to act, anticipating events. In 2007, it established a subsidiary in Albania. In 2008, VestoBene sold $85 \%$ of its products abroad and $30 \%$ of purchased volume compared to imports. It was active in 24 countries and had six legal entities in other countries.

Figure 2 summarizes the change of internationalization speed in this case. Just 2 years after inception, VestoBene began to internationalize through sales. The speed of sales growth was then maintained at a stable level for 4 years before it began to decelerate after 10 years of existence. Its international sales were at that point approximately $75 \%$ of turnover. Still, 16 years after inception, the firm was not purchasing any products abroad. However, it had begun to source abroad, thus the growth of the volume sourced from abroad accelerated. After 10 years of existence, the firm acquired a German firm. The speed of establishment of legal entities accelerated to a level where a new entity was established almost every second year for the next 12 years. The growth in the number of foreign markets underwent three phases. In the first phase, from the first to the fourth year of internationalization, growth occurred at a high speed, when the firm entered approximately four new markets every year. Then a period of deceleration occurred, lasting for 10 years before growth once more began to accelerate. 


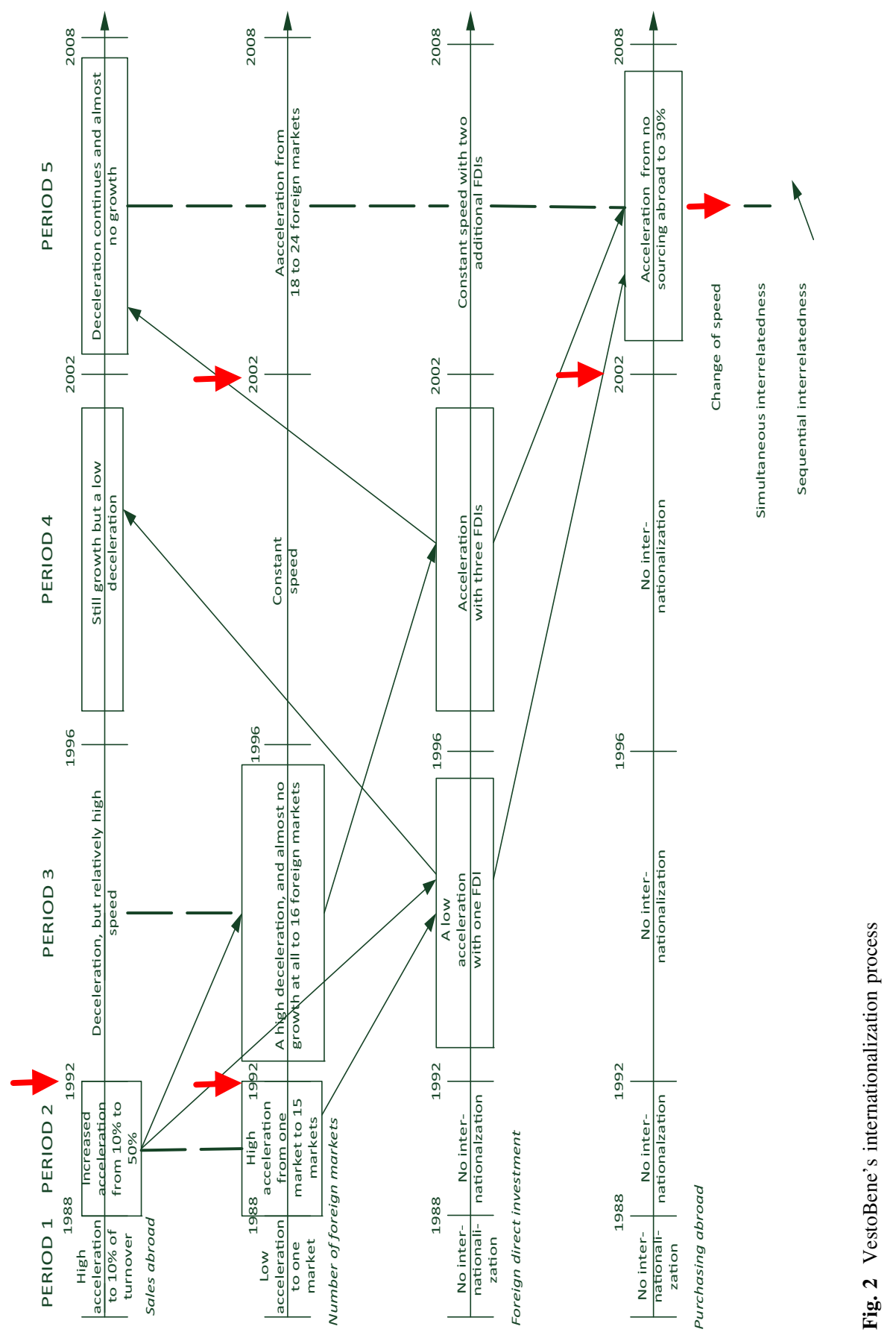


The case histories of Yamatek and VestoBene illustrate our argument that the internationalization process, studied from the point of view of the speed of internationalization, is more complex than the literature so far has indicated. Most studies assume the process to consist of only one commitment sequence - the evolution of international sales (e.g., Khavul et al. 2010; Ramos et al. 2011) - and taking place at a constant speed. In order to deal with such a complex phenomenon, previous studies on speed often refer to other studies of the speed concept as though the various commitment sequences were of the same nature and perfectly comparable. Our case examples illustrate that the speed and acceleration of one commitment sequence may vary from that of another. For example, the speed of establishment of legal entities is different from the speed of increase in the number of foreign markets in which the firm is operating. When, for instance, VestoBene's sales and number of markets decelerated in 1992-1996, the number of legal entities accelerated, and during the following 6 years all four pathways varied in terms of their speed. However, Yamatek undertook an intensive internationalization effort with acceleration or constant high speed of three of the four forms of commitment (only sourcing remained a mainly domestic activity) during a six-year period, after which there was sudden deceleration. At this time, instead, sourcing abroad accelerated. We therefore claim that it is necessary to be cautious when measuring speed or change of speed without specifying which aspect of internationalization is studied.

In this section, we have traced the different commitment activities that the two case firms undertook in their international expansion. We have also identified the critical incidents for each case; that is, the changes in speed that took place. For each firm, we have therefore identified its internationalization pattern, encompassing not just the evolution of its international sales, but also its foreign sourcing, establishment of legal entities, and geographical expansion. However, it still remains for us to provide a theoretical explanation for these patterns of acceleration and deceleration. How can we account for the change in speed? This is the task to which we now turn.

\section{Causes of Acceleration and Deceleration}

As our cases from the previous section illustrate, it cannot be assumed that any of the commitment sequences follow a smooth and even development; rather, change of speed characterizes the internationalization process. During some periods the speed is constant; during other periods internationalization accelerates or decelerates. In accounting for changes in speed, we first consider why a sequence of the same type of commitment activity is likely to experience variations in speed. We then move on to discuss how the multiple commitment activities affect each other.

\subsection{Change within a Single Commitment Sequence}

We illustrate examples of changes in speed within a single sequence of commitment activities in Figs. 1 and 2 by marking them with a thick vertical arrow. The change 
can be of two types. The first occurs when the firm goes from constant speed or acceleration and begins to decelerate a commitment activity, while the second change takes place when the firm starts to accelerate a commitment activity after periods of deceleration or constant speed. We argue that the former is due to challenges in making use of newly acquired knowledge, while the latter is the result of identifying and exploiting new opportunities.

\subsubsection{From Acceleration to Deceleration: The Challenges of Integrating Knowledge}

Both cases provide illustrations of the change from acceleration to deceleration. For instance, VestoBene internationalized at a high and accelerated speed from 1986 to 1992. Both international sales and the number of markets entered increased, but from 1992 international growth decelerated significantly. Yamatek also had a long period, from 1992 to 2001, with sustained acceleration, before internationalization of sales and number of markets decelerated.

Based on internationalization process theory, we propose that the main reason for the deceleration lies in three principal problems: acquiring knowledge, integrating knowledge, and coordinating and allocating resources. Turning to the first problem, when the firm needs to integrate extra knowledge, but does not have sufficient resources to do so, it requires some time to create/acquire the necessary resources before moving forward. Such resources may be in the form of hiring people with specific skills, developing routines for decision-making and communication, and sharing knowledge within the firm. Second, when the firm gains new knowledge which it cannot handle without high costs and problems, it needs to consolidate and to develop routines that will enable it to make full use of this knowledge. Third, internationalization implies growth and an increasing number of commitment activities to coordinate and control, which increases complexity, as the different activities are interrelated rather than independent. This calls for more information and better decision-making routines for, and communication with, foreign markets. Over shorter time periods, firms can accelerate, for instance, sales or sourcing abroad, but as this leads to the accumulation of a greater body of experience in a short period of time, they need to absorb and integrate this knowledge. This requires time and consequently forces the firm to decelerate (Dierickx and Cool 1989; Vermeulen and Barkema 2002). By doing this, the firm slows down its rate of knowledge acquisition but can concentrate on making sense of the already acquired knowledge.

We posit that the more a specific period is characterized by high or increasing acceleration, the more likely it is that a period of sudden and sharp deceleration will follow. The reason is partly to be found within the nature of the commitment activities, as the more complex they are, the more additional knowledge the firm has to absorb and integrate, and it may face difficulties in accomplishing this during a short period of time. A complex commitment consists of several interrelated activities and resources. For instance, establishing a legal entity is more complex than export, as the legal entity can imply not only selling but very often also sourcing from local suppliers, hiring people, starting production, taking care of legal 
issues, and so on. The complexity lies not only in each of these activities but also in how they interrelate. Managing this complexity requires greater stocks of knowledge and resources than exporting.

This means that it is not the gaining of experience-by definition the firm accumulates experience when exposed to new environments when internationalizing one of the dimensions - that is the main constraint, but rather it is the integration and subsequent transformation of the experience into useful capabilities, if this is all happening rapidly. Each commitment sequence will show variations in speed due to the requirement for specific capabilities and routines, as well as specific resource investments, and only part of the knowledge integrated can be reused in different markets or different commitments (Eriksson et al. 1997). An extreme case is when the firm decelerates so much that it begins to de-internationalize, which happens when the speed has reduced to the extent that the firm begins to lower the number of FDIs, lower the exports, lower the imports, and/or lower the number of markets where it is present. When the deceleration becomes so strong that the firm begins to de-internationalize a commitment activity, it does not necessarily take place across all the commitment activities. Thus, a firm can, for instance, de-internationalize its number of FDIs, while still accelerating its exports or imports.

\subsubsection{From Deceleration to Acceleration: Exploiting Opportunities}

The second type of change of speed shown in Figs. 1 and 2 is when the firm goes from either constant speed or deceleration to a period of acceleration. An example of this is when VestoBene, after 10 years of deceleration and constant speed of entering new markets, in 2002 begins a high acceleration and during the next 6 years enters one new market per year. Such a development did not happen in Yamatek's case. The three first periods, stretching from 1992 to 2001, are mainly characterized by acceleration and, in some cases, constant speed.

Such a change of speed is likely to be driven by the firm recognizing and beginning to exploit opportunities (Mainela et al. 2014). Opportunities related to the different commitment activities are new and valuable customers, suppliers, products, technologies, etc., which are perceived to have a positive influence on growth. As long as the firm is able to recognize opportunities and exploit them, its internationalization process is likely to accelerate. Following the same line of reasoning as above, it is logical to suppose that the firm develops routines and organizational structure prior to the period the acceleration starts. Consequently, changes in speed can be viewed as an integral part of the internationalization process: acceleration is followed by either deceleration or a period of constant speed, and vice versa. This leads to the revelation that decision-makers in the firm often have to manage changing speeds of the various sequences.

\subsection{Multiple Commitment Sequences}

In our conceptualization, the different forms of international commitment are interrelated and have a tendency to influence each other. We distinguish two types of interrelatedness: simultaneous and sequential. We discuss each in turn. 


\subsubsection{Simultaneous Interrelatedness}

Simultaneous interrelatedness occurs when the changes in speed in two or more commitment sequences are interdependent and interact during a specific period. For example, acceleration of sales abroad may go hand in hand with acceleration in the number of markets entered, and this interrelatedness is likely to be prevalent in the first periods of internationalization of SMEs and if the entered markets are relatively small. In Figs. 1 and 2, the dotted vertical lines visualize this interrelatedness during specific periods. In the example, it is visible in three periods of the internationalization process, where the first concerns the interplay between sales abroad and number of foreign markets. The development of these activities follows each other throughout the process in both our illustrative cases. In VestoBene's case, acceleration of these two dimensions characterizes 1986-1992, while deceleration dominates the subsequent 6 years. In this case the accelerating sales growth abroad is linked to entry into new foreign markets.

A second example of simultaneous interrelatedness occurs in the later periods, when both firms are fairly internationalized. Particularly in Yamatek's case, the four dimensions have the same speed throughout the process, which could be interpreted as their being integrated and interrelated and following the same rhythm during these periods. The need for integration of different commitment activities requires coordination, which takes time, and from this it follows that deceleration occurs.

\subsubsection{Sequential Interrelatedness}

Interrelatedness can also be sequential, which implies a temporal causality; that is, a change of speed in one dimension is a prerequisite for a change in the speed of another dimension in the following period. For instance, acceleration in one dimension during one period can be necessary for the deceleration of another dimension during the subsequent period. The arrows in Figs. 1 and 2 visualize several chains of sequentially interrelated dimensions. For instance, higher acceleration of sales abroad and expansion into new markets in the first two periods leads to an accelerated increase in the number of FDIs during the third period, in both our illustrative cases.

Another form of sequential interrelatedness, contributing to the dynamism of the process, is to be found in the acceleration of FDI activity, which with some lead-time results in accelerated purchasing abroad. For example, in the VestoBene case, FDI was also the cause of starting, somewhat later, foreign sourcing. As in the cases of both Vestobene and Yamatek, establishment of a legal entity in the foreign market entailed setting up production; they subsequently began to source foreign suppliers for this production facility, which provided the insight that they could also source from abroad for their domestic production. In line with Johanson and Vahlne (2009), this type of sequential interrelatedness results from opportunities being seized as a consequence of the firm's commitment to foreign markets. A succession of commitment in one dimension is a platform from which firms identify opportunities for other types of activities, which then accelerate too. 
In both these cases, acceleration during one or two periods results in acceleration of other commitment sequences during the following periods.

However, the interrelatedness of activities can also result in the acceleration of one commitment sequence causing the deceleration of another. For example, establishing an accelerated number of FDIs during one or two periods-from 1992 to 2002 in the VestoBene's case, and between 1995 and 2001 in Yamatek's case-leads to the deceleration of both sales abroad and number of foreign markets entered, even if the expansion continues. For SMEs, establishing FDIs abroad is a complex endeavor, which requires knowledge and resources, especially management time. As firms - especially SMEs - have limited resources, we argue that at certain times they have to concentrate their efforts on one activity, decelerating other activities, in order to consolidate their international operations.

The start of internationalization implies acceleration, and a limited number of activities are involved (typically one or two). Interrelatedness between different commitment sequences is limited, and acceleration is a consequence of the fact that the firm starts with no international activities at all. In the two illustrative cases, the process starts with a strong interrelatedness between sales abroad and number of markets, and with both accelerating. The interplay between the two types of activities triggers acceleration, which lasts for 6 years for VestoBene and 9 years for Yamatek. Generally, we argue that the initial simultaneous interrelatedness becomes more complex (in the way that it causes the changes in a later period, so the effects cannot be seen immediately) and is replaced by a sequential interrelatedness in later stages of the firms' internationalization when more dimensions are present (especially when FDIs are also established).

Thus, the dynamic that drives the process towards increased internationalization is a result of the interrelatedness among the activities. Typically, consolidation and integration take place when the firm is engaged in several activities. A slowdown in one commitment sequence can therefore be preparatory, or even be the cause, for a change in speed of another commitment activity in a subsequent period. An important consequence is that deceleration, or even de-internationalization, of one commitment sequence does not necessarily imply negative international performance overall.

\section{Final Remarks}

By adopting a processual and dynamic view on internationalization, we develop the concepts of acceleration and deceleration, thus providing analytical tools that can be useful for enhancing our understanding of the non-linearity and complexity of internationalization processes. We account for acceleration and deceleration by building on the concepts of opportunity recognition, knowledge integration, and coordination. Thus, even if we exclude the network component (Johanson and Vahlne 2009), we empathize with the revised Uppsala Model, where the authors argue that the importance of opportunity recognition is exaggerated. Learning and recognizing opportunities are only one side of the coin.

When firms recognize opportunities they find something new that is of value to them. It tends to accelerate the process, as it promotes growth and profit. But, there 
is another side of the coin consisting of exploitation, integration, and coordination, which are activities that require time to perform, or otherwise costs tend to increase. Consequently, there is a limit to how many opportunities the firm can recognize and how much experience it can gain before it suffers diminishing returns. When the burden of integrating knowledge and the resources needed to exploit and coordinate the opportunities becomes too great, the firm is forced to decelerate internationalization. Here, one has to distinguish between experience and useful experiential knowledge, where the latter is experience that has been absorbed and integrated into routines and structures in order to be useful and therefore has a favorable influence on internationalization.

By explicitly accounting for time, it emerges that internationalization is usually not a linear process as it undergoes periods of acceleration, deceleration, and also of constant speed. The extant literature on internationalization has difficulties in conceptualizing non-linear and irregular processes (for an exception, see Vissak and Francioni 2013). However, the concepts of acceleration and deceleration make this advance possible, which is a key contribution of this study. The non-linearity of the process is a result of the complexity of the commitment activity, the time the firm takes to go from recognizing opportunities to exploiting them, and the time it takes to go from accumulating experience with particular commitment activities to turning the experience into useful knowledge.

Further, this study underlines the weakness of limiting internationalization to only one type of activity, especially in a temporal and processual context, as the dimensions develop different patterns and might affect each other. One cannot talk about the speed of internationalization in general, but rather one has to specify the types of activities studied, as they follow a different logic. However, even though in this paper we have adopted a broader view on internationalization speed than has been used previously, the limitation to four types of commitment activities raises the question of whether there are other activities with a higher explanatory value.

Our point of departure was a traditional view on international commitment, but still, speed may have other components than the four employed; future research could provide other dimensions such as alliances, R\&D and innovation, for example. Since Johanson and Vahlne's work, other perspectives on commitment have emerged (Freeman and Cavusgil 2007; Hadjikhani 1997; Sharma et al. 2006; Blankenburg Holm et al. 1999), reflecting the attitudes and interests of the managers as well as intangible assets and skills invested in foreign markets, business relations, and networks. Those types of commitment may better capture the internationalization of knowledge- and service-intensive firms, as many of the theories build on the implicit assumption that firms produce and sell physical products. Also, the examples offered in this paper have been based on the manufacturing sector, yet it would be expected that commitment patterns and activities would vary across industries.

In addition, it is important to be cautious about conclusions drawn from these measures of commitments, as each of them contains bias. For instance, establishing a small sales office in a small, geographically and culturally close country is a completely different size and type of commitment than starting production in a populous country on the other side of the globe. Thus, both legal entities and markets are heterogeneous concepts. Another limitation is that the measures of 
commitment are not directly comparable. Export and import are expressed as percentages of the total volume, while legal entities and number of markets are expressed in cardinal numbers. Further, some commitment activities are often linked: for example, increasing percentage of exports and number of foreign markets.

This study refers to the literature on SME internationalization, and the examples are SMEs. That helped to delimit the study and to give it focus. In smaller firms it is easier to identify relations between different commitment activities, but we believe that the conclusions are valid for larger companies also; hence, future research should extend the boundaries and include multinational enterprises. The aim was to conceptualize acceleration and deceleration, but significant work is required to continue to integrate these concepts into the received theories on internationalization. So far, it has mostly been born global scholars who have discussed speed of internationalization, but we argue that this concept is not exclusive to a specific theoretical perspective. We therefore invite international business scholars to a debate on the internationalization process using diverse theoretical perspectives.

The current study is mostly theoretical. The use of empirical evidence is limited to exemplification, so researchers should explore the internationalization process in depth, and its evolution over time, using empirical studies, especially by employing longitudinal case studies. Studies of this kind would be able to test whether the theoretical explanation that we have provided withstands empirical scrutiny. In addition, we encourage researchers to explore the possibly negative consequences of change in speed on survival and growth of the firm. Another interesting area of research consists of exploring the skills and capabilities necessary to manage changes in speed during internationalization at the macro level, as well as during decision-making processes at the micro level.

Acknowledgments We are grateful to the editors of this special issue for their advice and comments on this paper. We would also like to thank Cipriano Forza, Jan Johanson and Mikael Hilmersson for their many constructive comments. The authors also appreciate the support of the European Commission through the Erasmus Staff Mobility Scheme.

Open Access This article is distributed under the terms of the Creative Commons Attribution 4.0 International License (http://creativecommons.org/licenses/by/4.0/), which permits unrestricted use, distribution, and reproduction in any medium, provided you give appropriate credit to the original author(s) and the source, provide a link to the Creative Commons license, and indicate if changes were made.

\section{Appendix}

\section{Data Collection and Analysis}

In this manuscript, we use two firms to exemplify our arguments. They are not used as the basis on which we draw our conclusions. Nevertheless, we collected and analyzed data following a rigorous approach. In each firm, we interviewed the 
Table 1 Source of data

\begin{tabular}{lll}
\hline Firm & Informants (length of interview) & Secondary data \\
\hline Yamatek & Entrepreneur & Balance sheets \\
& Production manager $(2.5 \mathrm{~h})$ & Internal documents \\
& & Website \\
VestoBene & Entrepreneur & Balance sheets \\
& Production manager $(2 \mathrm{~h})$ & Internal documents
\end{tabular}

entrepreneur and at least one other manager involved in the internationalization. In addition, we collected secondary data, such as balance sheets and various internal documents, and we visited the firms' headquarters (see Table 1). With the help of archival data, we analyzed variations in speed during the process.

We began by specifying the two end points of the process: the first was the inception of the firm and the second was the year in which the interviews were conducted. We then coaxed the informants to remember important events and points in time between these two end points. With the help of secondary data we were able to identify specific points in time, which we put on a timeline starting with inception and stretching to the time of the interview. By combining and comparing each sub-process between the points in time, we outlined the speed of export, import, number of legal entities established abroad, and number of foreign markets, and also how speed was changing. Once we had analyzed how the speed changed for each of the dimensions of international commitment, we aimed to find the determinants and outcomes for the changes.

\section{References}

Acedo, G. F. J., \& Jones, M. V. (2007). Speed of internationalisation and entrepreneurial cognition: Insights and a comparison between international new ventures, exporters and domestic firms. Journal of World Business, 42(3), 236-252.

Barrett, N. J., \& Wilkinson, I. F. (1986). Internationalisation behaviour: Management characteristics of Australian manufacturing firms by level of international development. In P. W. Turnbull \& S. J. Paliwoda (Eds.), Research in international marketing (pp. 213-233). Croom Helm: London.

Bell, J., McNaughton, R., Young, S., \& Crick, D. (2003). Towards an integrative model of small firm internationalisation. Journal of International Entrepreneurship, 1(4), 339-362.

Bilkey, W. J., \& Tesar, G. (1977). The export behaviour of smaller Wisconsin manufacturing firms. Journal of International Business Studies, 8(1), 93-98.

Blankenburg Holm, D., Eriksson, K., \& Johanson, J. (1999). Creating value through mutual commitment to business network relationships. Strategic Management Journal, 20(5), 467-486.

Butterfield, L. D., Borgen, W. A., Amundson, N. E., \& Maglio, A. S. T. (2005). Fifty years of the critical incident technique: 1954-2004 and beyond. Qualitative Research, 5(4), 475-497.

Casillas, J. C., \& Acedo, F. J. (2013). Speed in the internationalization process of the firm. International Journal of Management Reviews, 15(1), 15-29.

Casillas, J. C., \& Moreno-Menéndez, A. M. (2013). Speed of the internationalization process: the role of diversity and depth in experiential learning. Journal of International Business Studies, 45(1), 85-101.

Cavusgil, S. T. (1980). On the internationalization process of firms. European Research, 8(November), 273-281.

Chetty, S., \& Campbell-Hunt, C. (2004). A strategic approach to internationalisation: A traditional versus "born global" approach. Journal of International Marketing, 12(1), 57-81.

Chetty, S., Johanson, M., \& Martin Martin, O. (2014). Speed of internationalization: Conceptualization, measurement and validation. Journal of World Business, 49(4), 633-650. 
Coeurderoy, R., \& Murray, G. (2008). Regulatory environments and the location decision: Evidence from the early foreign market entries of new-technology-based firms. Journal of International Business Studies, 39(4), 670-687.

Contractor, F. J. (2007). Is international business good for companies? The evolutionary or multistage theory of internationalization or the transaction cost perspective. Management International Review, 47(3), 453-475.

Coviello, N. (2006). The network dynamics of international new ventures. Journal of International Business Studies, 37(5), 713-731.

Dierickx, I., \& Cool, K. (1989). Asset stock accumulation and sustainability of competitive advantage. Management Science, 35(12), 1504-1511.

Doz, Y. (2011). Qualitative research for international business. Journal of International Business Studies, 42(5), 582-590.

Eriksson, K., Johanson, J., Majkgård, A., \& Sharma, D. (1997). Experiential knowledge and cost in the internationalization process. Journal of International Business Studies, 28(2), 337-360.

Flanagan, J. C. (1954). The critical incident technique. Psychological Bulletin, 51(4), 327-358.

Freeman, S., \& Cavusgil, S. T. (2007). Toward a typology of commitment states among managers of born-global firms: A study of accelerated internationalization. Journal of International Marketing, 15(4), 1-40.

Hadjikhani, A. (1997). A note on the criticisms against the internationalization process model. Management International Review, 37(2), 43-66.

Hedlund, G., \& Kverneland, A. (1985). Are strategies for foreign markets changing? The case of Swedish investment in Japan. International Studies of Management and Organization, 15(2), 41-59.

Hewerdine, L., \& Welch, C. (2013). Are international new ventures really new? A process study of organizational emergence and internationalization. Journal of World Business, 48(4), 466-477.

Hilmersson, M., \& Johanson, M. (2015). Speed of SME internationalization and performance. Management International Review, 56(1), 67-94.

Jiang, R. J., Beamish, P. W., \& Makino, S. (2014). Time compression diseconomies in foreign expansion. Journal of World Business, 49(1), 114-121.

Johanson, M., \& Martin Martin, O. (2015). The incremental expansion of born internationals: A comparison of new and old born internationals. International Business Review, 24(3), 476-496.

Johanson, J., \& Vahlne, J.-E. (1977). The internationalisation process of the firm: A model of knowledge development and increasing foreign market commitment. Journal of International Business Studies, $8(1), 23-32$.

Johanson, J., \& Vahlne, J.-E. (2009). The Uppsala internationalization process model revisited: From liability of foreignness to liability of outsidership. Journal of International Business Studies, 40(2), 1411-1431.

Johanson, J., \& Wiedersheim-Paul, F. (1975). The internationalisation of the firm: Four Swedish cases. Journal of Management Studies, 12(3), 305-322.

Kalinic, I., \& Forza, C. (2012). Rapid internationalization of traditional SMEs: Between gradualist models and born globals. International Business Review, 21(4), 694-707.

Kalinic, I., Sarasvathy, S. D., \& Forza, C. (2014). 'Expect the unexpected': Implications of effectual logic on the internationalization process. International Business Review, 23(3), 635-647.

Karlsen, T., Silseth, P. R., Benito, G. R., \& Welch, L. S. (2003). Knowledge, internationalization of the firm, and inward-outward connections. Industrial Marketing Management, 32(5), 385-396.

Khavul, S., Pérez-Nordtvedt, L., \& Wood, E. (2010). Organizational entrainment and the internationalization of new ventures from emerging markets. Journal of Business Venturing, 25(1), 104-119.

Knight, G., \& Cavusgil, S. T. (1996). The born global firm: A challenge to traditional internationalisation theory. Advances in international marketing (pp. 11-26). JAI Press.

Li, L. (2007). Multinationality and performance: A synthetic review and research agenda. International Journal of Management Reviews, 9(2), 117-139.

Lin, W.-T. (2012). Family ownership and internationalization processes: Internationalization pace, internationalization scope, and internationalization rhythm. European Management Journal, 30(1), 47-56.

Luo, Y., Zhao, J. H., \& Du, J. (2005). The internationalization speed of e-commerce companies: An empirical analysis. International Marketing Review, 22(6), 693-709.

Madsen, T. K., \& Servais, P. (1997). The internationalisation of born globals: An evolutionary process? International Business Review, 6(6), 561-583. 
Mainela, T., Puhakka, V., \& Servais, P. (2014). The concept of international opportunity in international entrepreneurship: A review and a research agenda. International Journal of Management Reviews, 16(1), 105-129.

McDougall, P. P., Oviatt, B. M., \& Shrader, R. C. (2003). A comparison of international and domestic new ventures. Journal of International Entrepreneurship, 1(1), 59-82.

Moon, J., \& Lee, H. (1990). On the internal correlates of export stage development: An empirical investigation in the Korean electronics industry. International Marketing Review, 7(5), 16-26.

Morgan-Thomas, A., \& Jones, M. V. (2009). Post-entry dynamics: Differences between SMEs in the development speed of their international sales. International Small Business Journal, 27(1), 71-97.

Musteen, M., Francis, J., \& Datta, D. K. (2010). The influence of international networks on internationalization speed and performance: A study of Czech SMEs. Journal of World Business, 45(3), 197-205.

Oviatt, B. M., \& McDougall, P. P. (2005). Defining international entrepreneurship and modelling the speed of internationalization. Entrepreneurship Theory and Practice, 29(5), 537-553.

Pedersen, T., \& Petersen, B. (1998). Explaining increasing resource commitment to a foreign market. International Business Review, 7(5), 483-501.

Pla-Barber, J., \& Escribá-Esteve, A. (2006). Accelerated internationalisation: Evidence from a late investor country. International Marketing Review, 23(3), 255-278.

Ramos, E., Acedo, F. J., \& Gonzalez, M. R. (2011). Internationalisation speed and technological patterns: A panel data study on Spanish SMEs. Technovation, 31(10-11), 560-572.

Servais, P., Madsen, T. K., \& Rasmussen, E. S. (2007a). Small manufacturing firms' involvement in international e-business activities. Advances in International Marketing, 17, 301-321.

Servais, P., Zucchella, A., \& Palamara, G. (2007b). International entrepreneurship and sourcing: International value chain of small firms. Journal of Euromarketing, 16(1-2), 105-117.

Sharma, N., Young, L., \& Wilkinson, I. (2006). The commitment mix: Dimensions in international trading relationships in India. Journal of International Business Studies, 14(3), 64-91.

Shrader, R. C., Oviatt, B. M., \& McDougall, P. P. (2000). How new ventures exploit trade-offs among international risk factors: Lessons for the accelerated internationalisation of the 21 st century. Academy of Management Journal, 43(6), 1227-1247.

Vermeulen, F., \& Barkema, H. (2002). Pace, rhythm, and scope: Process dependence in building a profitable multinational corporation. Strategic Management Journal, 23(7), 637-653.

Vissak, T., \& Francioni, B. (2013). Serial nonlinear internationalization in practice: A case study. International Business Review, 22(6), 951-962.

Wagner, H. (2004). Internationalization speed and cost efficiency: Evidence from Germany. International Business Review, 13(4), 447-463.

Weerawardena, J., Mort, G. S., Liesch, P. W., \& Knight, G. (2007). Conceptualizing accelerated internationalization in the born global firm: A dynamic capabilities perspective. Journal of World Business, 42(3), 294-306.

Welch, L. S., \& Luostarinen, R. K. (1988). Internationalization: Evolution of a concept. Journal of General Management, 14(2), 34-55.

Welch, L. S., \& Luostarinen, R. K. (1993). Inward-outward connections in internationalisation. Journal of International Marketing, 1(1), 44-56.

Zhou, L. (2007). The effects of entrepreneurial proclivity and foreign market knowledge on early internationalization. Journal of World Business, 42(3), 281-293.

Zhou, L., Wu, W., \& Luo, X. (2007). Internationalization and the performance of born-global SMEs: The mediating role of social networks. Journal of International Business Studies, 38(4), 673-690.

Zucchella, A., Palamara, G., \& Denicolai, S. (2007). The drivers of the early internationalization of the firm. Journal of World Business, 42(3), 268-280. 